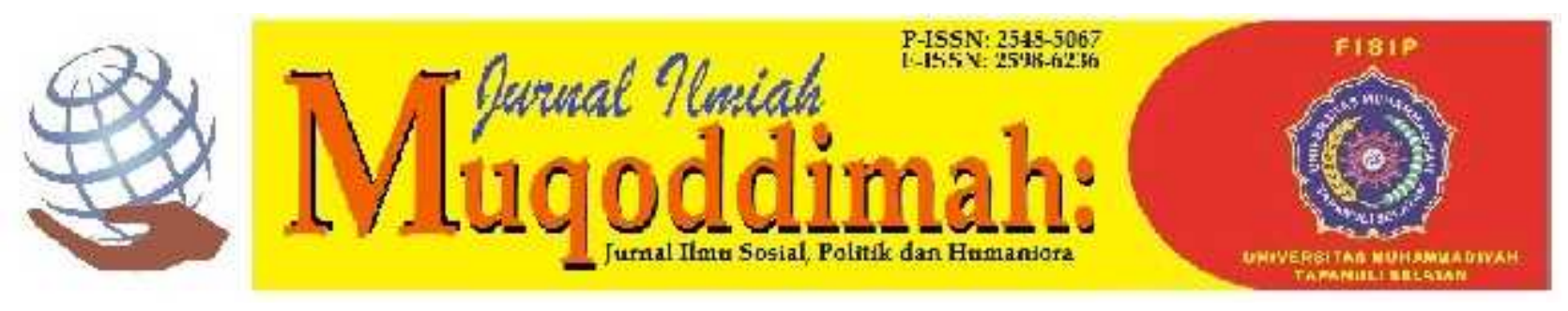

\title{
Peran Pemerintah Daerah dalam Memberdayakan Usaha Mikro Kecil dan Menengah di Kabupaten Tuban
}

\author{
Ertien Rining Nawangsari ${ }^{1)}$, Eva Yulia Fridayanti ${ }^{2)}$, Aktivani Inas Almira ${ }^{3)}$ \\ Riyaya Hajja Nugrohowati ${ }^{4)}$
}

UPN Veteran Jawa Timur

Jalan Raya Rungkut Madya, Gunung Anyar, Surabaya, Indonesia

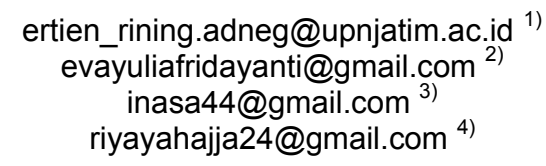

\begin{abstract}
Abstrak
Pemerintah Kabupaten Tuban kembali meraih Penghargaan Piala Natamukti dari International Council for Small Business (ICSB) Indonesia dan Kementerian Koperasi dan Usaha Kecil dan Menengah (KUKM). Penghargaan tersebut diraih karena Pemerintah Kabupaten Tuban dinilai sukses mendorong keberlangsungan Usaha Mikro Kecil Menengah (UMKM). Penghargaan ini sebagai tanda bukti keberhasilan pemerintah daerah dalam memasarkan dan mendorong peningkatan kualitas, serta membangun Usaha Mikro Kecil Menengah di daerahnya, dan juga Kabupaten Tuban masuk dalam daftar lima Kabupaten yang berhasil mengekspor dagang usaha mikro, kecil, dan menengah. Metode penelitian yang digunakan adalah metode penelitian Kualitatif dengan pendekatan deskriptif dengan menggunakan Teori dari Gede Diva dalam pemberdayaan Usaha Mikro, Kecil, dan Menengah di Kabupaten Tuban yang efektif dan optimal. Metode deskriptif adalah metode yang mendeskriptifkan suatu keadaan atau fenomena dengan tujuan untuk menggambarkannya berdasarkan fakta. Oleh karena itu, penelitian ini bertujuan untuk mendeskripsikan peran pemerintah daerah dalam pengembangan Usaha Mikro, Kecil, dan Menengah di Kabupaten Tuban dalam memasarkan produkproduk unggulan usaha mikro kecil dan menengah (UMKM). Kesimpulan penelitian ini adalah Pemerintah Kabupaten Tuban sudah melaksanakan tugas sebagai fasilitator, regulator, dan katalisator dalam proses pemberdayaan usaha mikro, kecil, dan menengah. Tetapi pemberdayaan tersebut belum dilakukan seacara menyeluruh di setiap desa dan kecamatan di Kabupaten Tuban.
\end{abstract}

Kata kunci: Kabupaten Tuban; Peran Pemerintah Daerah; UMKM

\begin{abstract}
The Tuban Regency Government again won the Natamukti Cup Award from the International Council for Small Business (ICSB) Indonesia and the Ministry of Cooperatives and Small and Medium Enterprises (KUKM). The award was achieved because the Tuban Regency Government is considered successful in encouraging the sustainability of Small and Medium Micro Enterprises (MSMEs). This award is a proof of the success of the local government in marketing and encouraging quality improvement, as well as building Small and Medium Micro Enterprises in the region, as well as Tuban Regency is included in the list of five districts that successfully export micro, small, and medium enterprises. The
\end{abstract}




\begin{abstract}
research method used is Qualitative research method with descriptive approach by using Gede Diva theory in empowering Micro, Small, and Medium Enterprises in Tuban Regency that is effective and optimal. Descriptive method is a method that descripts a state or phenomenon with the aim of describing it based on facts. Therefore, this study aims to describe the role of local governments in the development of Micro, Small, and Medium Enterprises in Tuban Regency in marketing the superior products of small and medium-sized micro enterprises (MSMEs). The conclusion of this research is that the Tuban District Government has carried out its duties as a facilitator, regulator, and catalyst in the process of empowering micro, small, and medium enterprises. But the empowerment has not been done thoroughly in every village and sub-district in Tuban Regency.
\end{abstract}

Key words: MSMEs; Regency of Tuban; Role of Local Government

\title{
PENDAHULUAN
}

Dalam UU Nomor 20 tahun 2008 yang dimaksud dari Usaha Mikro Kecil dan Menengah (UMKM) adalah sebuah usaha ekonomi produktif yang biasanya dimiliki oleh perorangan atau kumpulan kelompok dengan ketentuan yang telah ditetapkan dalam undang-undang. Ketentuan dalam undang-undang tersebut diantaranya yaitu, Usaha mikro adalah usaha yang berprofit milik perorangan dan atau badan usaha yang memenuhi kriteria, mempunyai kekayaan usaha bersih paling tinggi sebesar Rp50.000.000,00 (lima puluh juta rupiah) non tanah usaha dan bangunan yang digunakan untuk usaha atau mempunyai keuntungan tahunan paling tinggi sebesar Rp300.000.000,00 (tiga ratus juta rupiah).

Usaha Kecil merupakan usaha ekonomi produktif yang berdiri sendiri, oleh perorangan atau yang bukan bagian dari perusahaan manapun. Usaha Menengah atau Usaha Besar dengan memenuhi kriteria mempunyai kekayaan bersih lebih dari Rp50.000.000,00 (lima puluh juta rupiah) sampai dengan paling banyak Rp500.000.000,00 (lima ratus juta rupiah) non tanah dan bangunan tempat usaha atau mempunyai profit hasil penjualan tahunan lebih dari Rp300.000.000,00 (tiga ratus juta rupiah) sampai dengan paling banyak Rp2.500.000.000,00 (dua milyar lima ratus juta rupiah).

Usaha Menengah adalah usaha ekonomi produktif mandiri, dengan kepemilikan perorangan atau badan yang bukan cabang atau bagian dari perusahaan lain. Bisa disebut usaha menengah jika memenuhi kriteria dengan pendapatan bersih lebih dari Rp $500.000 .000,00$ (lima ratus juta rupiah) dan paling banyak Rp 10.000.000.000,00 (Sepuluh milyar rupiah) non tanah dan bangunan usaha atau mempunyai hasil penjualan tahunan lebih dari $\mathrm{Rp} 2.500 .000 .000,00$ (dua milyar lima ratus juta rupiah) hingga nominal paling besar sebesar Rp 50.000.000.000,00 (lima puluh milyar rupiah).

Tujuan utama dibentuk UMKM adalah untuk mendorong laju perekonomian negara. UMKM ini juga terbukti tahan banting, dibuktikan ketika Indonesia mengalami krisis ekonomi 1998 UMKM tetap bisa produktif. Selain itu UMKM juga menyumbang cukup besar untuk perekonomian suatu negara khususnya Indonesia. Sektor UMKM merupakan salah satu jalur utama dalam mengembangkan sistem ekonomi kerakyatan. Pembinaan perlu dilakukan guna mewujudkan pengembangan usaha nasional. Pembinaan terhadap UMKM akan membuat usaha mikro, kecil, hingga menengah berkembang secara mandiri, memperluas lapangan pekerjaan sehingga dapat berdampak pada peningkatan pendapatan masyarakat, serta dapat menyediakan produk dan jasa dalam negeri sehingga tidak perlu melakukan impor lagi ke negara lain.

Kabupaten Tuban merupakan sebuah daerah yang memberikan perhatian khusus terhadap pembinaan UMKM, pembinaan tersebut dilakukan dalam bentuk pemberdayaan. Dilansir dari Blok Tuban.com, Dinas Koperasi, Perindustrian dan Perdagangan (Diskoperindag) menjelaskan bahwa pada tahun 2019 jumlah UMKM di Kabupaten Tuban mencapai 75.536. Yang terdiri 48.436 pelaku usaha Pertanian, 11.404 pelaku usaha Perdagangan, 1.587 pelaku Produk Olahan, 2.120 pelaku Jasa, dan 11.989 pelaku Aneka Usaha. Dan di akhir tahun 2019 jumlah UMKM di Kabupaten Tuban semakin meningkat yaitu berjumlah 93.112 unit, yang tersebar di 328 desa/kelurahan dan di 20 wilayah kecamatan 
Bumi Wali Tuban. Dengan semakin meningkatnya jumlah UMKM di Kabupaten Tuban diharapkan mampu untuk menyerap tenaga kerja sehingga harapannya tingkat pengangguran di Kabupaten Tuban lajunya dapat di tekan.

Dikutip dari Jawa Pos Radar Bojonegoro, pada tahun 2020 ada empat UMKM di Kabupaten Tuban yang lolos produk eskpor. Jenis produk tersebut adalah UMKM di bidang kerajinan, diantaranya Kerajinan Kayu Jati, Kerajinan Sepatu Safety, Kerajinan Batik dan Batik Gedog. Tentunya hal tersebut tidak lepas dari peran pemerintah daerah Kabupaten Tuban yang terus mendukung para UMKM agar memiliki produk yang berkualitas sehingga produknya tidak hanya dijual di pasar lokal saja, tetapi harapannya dapat merambah hingga pasar global. Karena dinilai sukses dalam mengembangkan Usaha Mikro Kecil dan Menengah (UMKM), pemerintah Kabupaten Tuban memperoleh penghargaan Piala Namukti dari International Council for Small Business (ICSB) Indonesia dan Kementerian Koperasi dan Usaha Kecil dan Menengah (KUKM) pada tahun 2020. Penghargaan Namukti adalah penghargaan yang diberikan oleh International Council for Small Business (ICSB) kepada daerah yang memang mampu dalam melaksanakan pengembangan UMKM yang terpercaya, terdepan, dan teratur. Sehingga dapat dikatakan bahwa Kabupaten Tuban merupakan Kabupaten yang mampu untuk memberdayakan UMKM.

Di dalam Peraturan Daerah Kabupaten Tuban Nomor 11 tahun 2020, untuk mengembangkan serta meningkatkan potensi UMKM perlu dilakukan pemberdayaan oleh pemerintah daerah. Berdasarkan Undang- Undang nomor 20 tahun 2008 tentang Usaha Mikro, Kecil, dan Menengah, pemberdayaan merupakan usaha yang digarap Pemerintah Bersama antara Pemerintah, Pemerintah Daerah, Dunia Usaha, dan masyarakat dalam bentuk pengembangan iklim dan pengembangan usaha terhadap Usaha Mikro, Kecil, dan Menengah dengan harapan UMKM mampu tumbuh serta berkembang menjadi usaha yang tangguh dan mandiri.

Di Kabupaten Tuban, pemerintah daerah yang melaksanakan pemberdayaan UMKM adalah Dinas Koperasi Perindustrian dan Perdagangan (Diskoperindag). Pemberdayaan UMKM yang dilakukan yaitu dalam bentuk : pembinaan, bimbingan, pendidikan, pelatihan, penyuluhan, dan konsultasi kepada usaha mikro secara rutin dan berkelanjutan, pemberian bantuan pendampingan dan advokasi, pemberian penguatan permodalan melalui penyaluran dana bergulir, pemberian kemudahan fasilitas akses permodalan ke lembaga keuangan perbankan dan non perbankan, penciptaan dan pengembangan iklim dan kondisi yang mendorong pertumbuhan dan pemasyarakatan usaha mikro, pengupayaan tata hubungan usaha yang saling menguntungkan antara usaha mikro dengan badan usaha lainnya, serta pemberian insentif kepada usaha mikro.

Penelitian ini berfokus pada pendeskripsian bentuk dari peran pemerintah daerah yang diwakili oleh Dinas Koperasi, Perindustrian, dan Perdagangan dalam memberdayakan UMKM di Kabupaten Tuban. Menurut Soerjono Soekanto (2002:243) Peran merupakan hasil dari seseorang atau badan ketika mereka menjalankan tanggung jawab sesuai dengan kedudukan yang ia miliki. Maka hal tersebut sudah dikatakan seseorang atau badan tersebut telah menjalankan peran. Peran menurut Bruce J.Cohen dalam bukunya sosiologi suatu pengantar adalah "Suatu perilaku yang diharapkan oleh orang lain dari seseorang yang menduduki status tertentu (Cohen,2009:76). Menurut Miftah Thoha, peranan merupakan serangkaian tindakan yang dilakukan oleh seseorang. Penghargaan semacam itu merupakan suatu norma yang dapat mengakibatkan terjadinya suatu peranan. Pada organisasi, peranan didapatkan dari uraian jabatan yang diemban. Adapun uraian jabatan itu merupakan dokumen tertulis yang memuat persyaratan-persyaratan dan tanggung jawab atas suatu pekerjaan. Karena hakikatnya peranan itu merupakan perwujudan interaksi antara orang-orang dalam organisasi. Dengan demikian banyak yang bisa dilakukan olehnya untuk merencanakan intervensi ke arah perubahan, perbaikan dan penyempurnaan organisasi (Thoha,2003:80).

Karena fokus dari penelitian ini adalah pada pendeskripsian bentuk dari peran pemerintah daerah yang diwakili oleh Dinas Koperasi, Perindustrian, dan Perdagangan 
dalam memberdayakan UMKM di Kabupaten Tuban, maka tujuan dilakukan penelitian ini yaitu untuk melihat sejauh mana peran Dinas Koperasi, Perindustrian dan Perdagangan selaku aktor pemberdaya pelaku UMKM sebagai pihak yang dikembangkan, karena apa yang dilakukan di Kabupaten Tuban merupakan best practice yang dapat direplikasikan ke daerah lain untuk peningkatan pendapatan masyarakat dan pengoptimalan potensi ekonomi daerah.

Penelitian yang dilakukan mengenai Peran Pemerintah Daerah dalam Memberdayakan UMKM di Kabupaten Tuban, peneliti membaca beberapa penelitian terdahulu yang sama sebagai bahan rujukan dalam penelitian ini, agar peneliti mendapatkan informasi lebih dan juga sebagai bahan pembanding, diantaranya adalah penelitian dibuat oleh Taranggana Gani Putra, yang terbit tahun 2015 di Fakultas IImu Sosial dan IImu Politik Universitas Airlangga dengan judul "Peran Pemerintah Daerah Dan Partisipasi Pelaku Usaha Dalam Pengembangan UMKM Manik-Manik Kaca di Kabupaten Jombang". Kedua, penelitian yang dilakukan dari Cristofer Ondang, Frans Singkoh, dan Neni Kumayas yang terbit tahun 2019 di Fakultas IImu Sosial dan IImu Politik Universitas Sam Ratulangi dengan judul "Peranan Pemerintah Daerah Dalam Pemberdayaan Usaha Mikro Kecil Menengah (UMKM) Di Kabupaten Minahasa (Suatu Studi Di Dinas Koperasi dan UKM). Ketiga, penelitian yang dilakukan Arina Hidayati dan Farah Dzil Barr terbit tahun 2019 di Universitas Selamet Sri dengan judul "Peran Pemerintah Daerah Dalam Pemberdayaan UMKM Berbasis One Village One Product (OVOP) Sebagai Gerakan Ekonomi Bernilai Kearifal Lokal (Studi Kasus Pada UMKM Batik Bagus Alam Dan Kerajinan Kulit Masin, Kabupaten Batang)".

Berdasarkan uraian dari ketiga penelitian tersebut peneliti menemukan beberapa kesamaan permasalahan yaitu diperlukan sebuah peran pemerintah daerah melalui Dinas Koperasi Perindustrian dan Perdagangan untuk memberdayakan UMKM agar para pelaku usaha tetap berdaya ditengah kepurukan perekonomian Indonesia, dan juga agar UMKM bisa naik kelas Mikro, Kecil menjadi Menengah sehingga memunculkan produk-produk UMKM yang mampu tembus pasar ekspor sehingga tidak hanya di tingkat nasional akan tetapi bisa sampai tingkat global.

Dari latar belakang diatas maka peneliti terinspirasi untuk meneliti terkait pemberdayaan sektor usaha mikro, kecil, dan menengah dengan judul "peran Pemerintah Daerah dalam Memberdayakan Usaha Mikro Kecil dan Menengah di Kabupaten Tuban".

\section{METODE}

Penelitian ini menggunakan metode penelitian Kualitatif dengan pendekatan deskriptif. Tujuan dari penelitian ini adalah menjelaskan bagaimana peran pemerintah daerah Kabupaten Tuban dalam memberdayakan Usaha Mikro Kecil Menengah (UMKM). Data akan diperoleh melalui Observasi, Wawancara, dan Dokumentasi. Penelitian ini menggunakan sumber data primer dan sumber data sekunder(Prof. Dr. Sugiyono, 2019).

Metode analisis data yang digunakan peneliti dalam penelitian kualitatif ini berupa model analisis data interaktif yang dikembangkan oleh Miles dan Huberman (1984), yang menjelaskan bahwa kegiatan dalam analisis data yaitu data reduction, data display, dan conclusion drawing/ verification.

Dalam penelitian ini, peneliti menggunakan dua teknik pemeriksaan kredibilitas data, yaitu menggunakan teknik ketekunan pengamatan dan teknik triangulasi. Ketekunan pengamatan artinya melakukan pengamatan secara lebih cermat dan berkesinambungan, sedangkan Teknik triangulasi merupakan uji keabsahan data dengan pengecekan dari berbagai sumber. Pada penelitian ini Triangulasi sumber dengan mengecek keabsahan data dari Pemerintah Kabupaten Tuban tepatnya pada Dinas Koperasi Perindustrian, dan Perdangangan, sumber berita dan masyarakat sedangkan triangulasi metode berasal dari metode wawancara, observasi, dan dokumentasi. 


\section{HASIL DAN PEMBAHASAN}

Teori dari Gede Diva, dalam pemberdayaan UMKM peran dari pemerintah yang efektif dan optimal dalam memberdayakan UMKM dapat terwujud dengan tiga indikator yaitu sebagai fasilitator, regulator dan katalisator:

1. Fasilitator

Pada tahun 2021, jumlah UMKM di Kabupaten Tuban mencapai lebih dari 200 ribu UMKM. Hal tersebut menandakan bahwa pemerintah daerah terus menerus mengembangkan dan memberdayakan UMKM di Tuban agar jumlahnya setiap tahun meningkat. Jenis UMKM di Kabupaten Tuban mulai dari makanan dan non makanan, seperti kripik bayam, kripik daun siri, kerajinan batik gedog, kerajinan kayu jati, kerajinan yang terbuat sampah, hingga lain sebagainya. Tetapi yang menjadi produk unggulan UMKM di Kabupaten Tuban adalah batik gedog dari kecamatan kerek. Tetapi diskoperindag belum memiliki visi misi paten untuk mendukung pemberdayaan UMKM di Kabupaten Tuban. Visi misi yang dimiliki masih mengikuti Provinsi Jawa Timur, yakni "UMKM Kuat Bangsa Berdaulat"

Berdasarkan hasil wawancara yang peneliti lakukan dengan staf Kasi Pemberdayaan dan Pembangunan Usaha yang dielaborasikan berdasarkan teori peran pemerintah daerah dalam memberdayakan UMKM di Kabupaten Tuban menurut Geo Diva sebagai fasilitator, regulator, dan katalisator.

Sebagai fasilitator, Dinas Koperasi, Perindustrian dan Perdagangan (Diskoperindag) mempunyai peran untuk memberikan fasilitas kepada UMKM. Hal tersebut dilakukan agar usaha yang dimiliki UMKM bisa berdaya serta berkembang, maju, hingga bisa mandiri. Fasilitas yang diberikan Diskoperindag untuk memberdayakan UMKM di Kabupaten Tuban yang pertama ialah melakukan pelatihan mulai dari pelatihan manajemen, lalu pemasaran dengan menghadiri pameran diluar kota, hingga pelatihan keuangan dalam mengelola usaha. Sedangkan yang kedua berupa evaluasi, dan yang ketiga adalah memberikan bantuan alat produksi. Untuk bantuan alat produksi, kerajinan batik di kecamatan kerek diberikan 10 alat tenun modern, sehingga diharapkan memudahkan mereka untuk memproduksi kerajinan batik. Fasilitas yang diberikan Diskoperindag ditunjukkan untuk kelompok UMKM di Kabupaten Tuban yang dilaksanakan setiap satu tahun 3 kali untuk pelatihan, dan dilaksanakan secara offline untuk memudahkan interaksi pelaku usaha dengan pemateri. Untuk evaluasi Diskoperindag turun langsung ke lapangan untuk mengecek perkembangan UMKM apakah mengalami kemajuan atau ada hambatan. Monitaring dan evaluasi ini dilakuan setiap 3 bulan sekali.

Sebenarnya kelompok UMKM batik gedog sudah diberikan alat produksi oleh Diskoperindag, akan tetapi banyak yang masih mengalami kesusahan dalam mengoperasikan alat tersebut. padahal sudah dilakukan pelatihan selama 3 bulan dan dilatih langsung oleh penjual alat produksi tersebut. Karena mereka lebih merasa nyaman dan biasa dengan alat yang tradisonal, selain itu produk yang dihasilkan dengan alat tradisional kualitasnya jauh lebih bagus daripada alat produksi modern. Untuk keberlanjutan alat produksi yang diberikan tetap digunakan akan tetapi untuk kerajinan batik yang menggunakan mesin modern harganya lebih murah sedangkan kerajinan batik yang diproduksi menggunakan alat tradisional harganya relatif lebih mahal, perbedaan harga tersebut karena adanya perbedaan pada kualitas batik yang dihasilkan. Batik yang dibuat dengan cara tradisional memiliki kualitas yang lebih baik daripada batik buatan mesin modern.

Di masa pandemi covid-19 UMKM di Kabupaten Tuban juga mendapatkan dana subsidi dari pemerintah pusat sebesar Rp. 2.400 .000 per orang, sedangkan dari pemerintah daerah Kabupaten Tuban memberikan dana subsidi sebesar Rp. 1000.000 untuk usaha kecil. Dan diharapakan dengan dana tersebut UMKM di masa 
pandemi tetap bisa bangkit dan beroperasi sehingga berimbas pada kestabilan ekonomi di Indonesia.

Jika UMKM terkendala dalam hal pendanaan, fasilitator memiliki tugas untuk ikut membantu menyelesaikan permasalahan tersebut, agar UMKM memperoleh dana yang dibutuhkan (Gede Diva.2009:15-18). Dinas Koperasi, Perindustrian, dan Perdagangan (Diskoperindag) Kabupaten Tuban juga melakukan hal tersebut yaitu dengan saling koordinasi bersama UMKM yang sedang mengalami kesulitan finansial, bahan baku, ataupun penjulan. Diskoperindag akan memfasilitasi apa saja yang disulitkan oleh UMKM tersebut. kalau UMKM kesulitan dalam hal pemasaran, maka akan dibantu pemasarannya bisa dengan melakukan pameran atau bisa juga berkerjasama dengan mitra seperti Indomaret yang ada di Kabupaten Tuban. Jadi produknya bias dijual di Indomaret tanpa membayar pajak, selain itu jika ada yang kesulitan dalam hal legalitas, maka akan dibantu perizinan legalitasnya.

2. Regulator

Peran Pemerintah sebagai regulator ialah Pemerintah membuat aturan atau kebijakan melalui perundang-undangan sehingga UMKM lebih mudah untuk menjalankan usahanya. Dalam melaksanakan fungsi regulator Pemerintah Daerah Kabupaten Tuban telah mengeluarkan Peraturan Daerah terbaru mengenai UMKM. Peraturan tersebut ialah Peraturan Daerah Kabupaten Tuban Nomor 11 Tahun 2020 Tentang Pemberdayaan dan Pengembangan Usaha Mikro. Dalam peraturan tersebut berisikan ketentuan lengkap yang dibutuhkan oleh UMKM, mulai dari pemberdayaan, pendataan, kemitraan, perizinan, perlindungan, permodalan, pengawasan, hingga pengaturan mengenai sanksi administratif. Dengan adanya peraturan tersebut menunjukkan bahwa Pemerintah Kabupaten Tuban telah melaksanakan peran regulator dengan baik.

Pemerintah Daerah Kabupaten Tuban melalui Dinas Koperasi Perindustrian dan Perdagangan atau biasa disingkat dengan Diskoperindag sangat memperdulikan dan benar-benar memikirkan UMKM di Kabupaten Tuban. Hal tersebut dibuktikan dengan adanya peraturan Titik Dagang Usaha di Kabupaten Tuban, dimana setiap orang yang mendaftarkan usahanya sebagai UMKM lebih tepatnya untuk usaha mikro di Diskoperindag maka akan diberi Titik Dagang Usaha. Tujuan pemberian titik ini adalah untuk menentukan titik lokasi berjualan tanpa harus berbentrokan dengan SATPOL PP. Selain diberikan titik lokasi dagang usaha, orang yang mendaftarkan usahanya sebagai UMKM akan didaftarkan dan diperkenalkan pada paguyuban sesuai denga jenis usaha dagangnya. Paguyuban tersebut dibentuk oleh Diskoperindag dengan tujuan untuk mendorong pertumbuhan UMKM menjadi satu ikatan yang kuat dan tidak terpecah-pecah.

3. Katalisator

Pada teori Gede diva dalam memberdayakan UMKM salah satunya adalah Peran Pemerintah Daerah sebagai katalisator. Dalam KBBI, katalisator artinya seseorang atau badan yang melakukan sesuatu dengan tujuan menyebabkan terjadinya perubahan dan menimbulkan kejadian baru atau mempercepat suatu peristiwa. Artinya disaat Pemerintah Daerah memberdayakan UMKM dan disini diwakilkan oleh Dinas Koperasi Perindustrian dan Perdagangan bertindak sebagai instansi yang mendorong terjadinya perubahan dan menstimulus pemberdayaan.

Dalam pemasaran, Diskoperindag mengadakan pameran dan juga memasang pamphlet produk UMKM tersebut pada pusat oleh-oleh. Peran Diskoperindag dalam memasarkan produk sampai ekspor adalah mengejar buyer atau penyalur untuk menjualkan Kembali produk UMKM ke luar negeri tanpa mengganti label suatu brand atau produk. Untuk memasarkan produk melalui digital, Diskoperindag memiliki aplikasi "penglariss", yang sangat mudah digunakan dan bisa didownload oleh khalayak umum melalui playstore. Dalam hal permodalan, 
Diskoperindag mengelola dana pinjaman "dagulir" dana bergulir yang bersumber dari kementerian, dan pencairannya melalui bantuan perbankan.

Dalam mempercepat proses berkembangnya UMKM, Diskoperindag memiliki tekad untuk mempercepat pemasaran, publikasi produk, karena semakin di pacu maka produk akan berkembang secara pesat. Dan juga Diskoperindag membantu mencarikan pangsa pasar yang sesuai dengan produk dari UMKM. Untuk membangkitkan semangat para pelaku UMKM, Pemerintah Daerah memberikan penghargaan kepada UMKM berprestasi. Dengan tujuan, agar para UMKM memiliki daya saing lebih untuk mendapatkan penghargaan tersebut.

Komitmen Diskoperindag dalam memberdayakan UMKM mini adalah mengharapkan UMKM bisa maju, mandiri dan UMKM bangkit. Dan harapan Diskoperindag dari pemberdayaan ini adalah untuk bisa membangun UMKM yang mandiri dan berkualitas.

\section{SIMPULAN DAN SARAN}

Kesimpulan yang peneliti dapat mengenai Peran Pemerintah Daerah Pemberdayaan UMKM di Kabupaten Tuban adalah, Pemerintah Kabupaten Tuban sudah melaksanakan tugas sebagai fasilitator, regulator, dan katalisator dalam proses pemberdayaan usaha mikro, kecil, dan menengah. Tetapi pemberdayaan tersebut belum dilakukan seacara menyeluruh di setiap desa dan kecamatan di Kabupaten Tuban.

Saran untuk Dinas Koperasi, Perindustrian, dan Perdagangan dalam memberdayakan UMKM di Kabupaten Tuban adalah pemberdayaan UMKM yang dilakukan Diskoperindag sudah baik, akan tetapi pemberdayaan tersebut belum menyeluruh dilakukan di setiap desa dan kecamatan di Kabupaten Tuban. Pemberdayaan lebih banyak dilakukan pada kecamatan Kerek, Kecamatan Montong, Kecamatan Rengel, Kecamatan Parengan, Kecamatan Jatirogo, Kecamatan Semanding. Sedangkan untuk kecamatan lainnya seperti Kecamatan Senori, dan Kecamatan Bangilan dalam hal pemberdayaan UMKM belum dilakukan secara optimal. Jadi diharapkan untuk kedepannya Pemerintah Kabupaten Tuban diwakili oleh Dinas Koperasi, Perdangangan, dan Perindustrian lebih memeratakan pemberdayaan di setiap kecamatan Kabupaten Tuban, agar roda perkonomian serta kesejahteraan masyarakat dapat menyuruh sehingga tidak hanya terpusat di beberapa kecamatan saja.

\section{UCAPAN TERIMAKASIH}

Terimakasih Kepada Dinas Koperasi, Perindustrian, dan Tenaga Kerja Kabupaten Tuban yang telah memberikan penjelasan kepada Penulis. Terimakasih kepada Ibu Dr. Ertien Rining Nawangsari, M.Si selaku Dosen Pembimbing. Dan terimakasih kepada seluruh teman- teman Administrasi Publik 2018, dan juga semua yang terlibat dalam penyusan artikel ilmiah ini.

\section{DAFTAR PUSTAKA}

Anoraga, y. B. (2017). Implementasi peraturan daerah kabupaten mojokerto nomor 19 tahun 2008 tentang pemberdayaan koperasi, usaha mikro, kecil, dan menengah di kecamatan sooko, kabupaten mojokerto. Publika, 5(5).

Definta, a. (2018). Upaya pemerintah daerah dalam pemberdayaan usaha mikro, kecil dan menengah (umkm) sentra industri konveksi dan bordir di desa padurenan, kecamatan gebog, kabupaten kudus (doctoral dissertation, diponegoro university).

Hartono, o. (2012). Kebijakan pemerintah mensinergikan sektor swadaya masyarakat (umkm) dan sektor korporasi dalam rangka membangun ekosistem industri kreatif untuk pertumbuhan dan pembangunan yang berbasis lingkungan. Semantik, 2(1).

Hidayati, a., \& barr, f. D. (2019). Peran pemerintah daerah dalam pemberdayaan umkm berbasis "one village one product (ovop) sebagai gerakan ekonomi bernilai kearifan lokal"(studi kasus pada umkm batik bagus warna alam dan kerajinan kulit masin, 
kabupaten batang). Ristek: jurnal riset, inovasi dan teknologi kabupaten batang, 4(1), 79-93.

http://bloktuban.com/2019/11/06/blokbeli-com-peluang-pemasaran-untuk-umkm-di-tuban/ http://bloktuban.com/2020/01/28/tahun-2019-ada-75-536-pelaku-umkm-di-tuban/

http://bloktuban.com/2020/09/18/berdayakan-umkm-bupati-tuban-dianugerahi-natamukti/

https://jatimpos.co/asal-tahu/3795-the-journey-of-toeban-meriahkan-hari-jadi-tuban-727

Https://radarbojonegoro.jawapos.com/read/2020/08/04/207394/lima-umkm-kerajinan-tuban-

lolos-program-ekspor

https://www.ukmindonesia.id/baca-artikel/62

Khusniyah, k. (2019). Implementasi triple helix meningkatkan hasil produksi krupuk umkm di kecamatan krembung kabupaten sidoarjo. Jurnal agriovet, 1(2), 197-210.

Modisane, p., \& jokonya, o. (2021). Evaluating the benefits of cloud computing in small, medium and micro-sized enterprises (smmes). Procedia computer science, 181, 784792.

Nabila, c., nur, t., \& amirulloh, m. R. (2021). Strategi dinas perdagangankoperasi dan ukm kabupaten sukabumi dalam pengembangan sektor usaha mikro \& kecil. Jurnal ilmiah muqoddimah: jurnal ilmu sosial, politik dan hummanioramaniora, 5(2), 1-9.

Nuhriawangsa, a. M. P., kartikasari, I. R., budiharjo, a., swastike, w., \& hertanto, b. S. Pengembangan potensi usaha abon untuk meningkatkan daya saing produk di umkm ksatria kelurahan jagalan, kecamatan jebres, surakarta. Agrihealth: journal of agri-food, nutrition and public health, 1(2), 103-109.

Ondang, c., singkoh, f., \& kumayas, n. (2019). Peranan pemerintah daerah dalam pemberdayaan usaha mikro kecil menengah (umkm) di kabupaten minahasa (suatu studi di dinas koperasi dan ukm). Jurnal eksekutif, 3(3)

Putra, t. G. (2015). Peran pemerintah daerah dan partisipasi pelaku usaha dalam pengembangan umkm manik-manik kaca di kabupaten jombang. Jurnal kebijakan dan manajemen publik, 3(1).

Prof. Dr. Sugiyono. (2019). Metode penelitian kuantitatif, kualitatif, dan r\&d (edisi kedua). Alfabeta.

Shafi, m., liu, j., \& ren, w. (2020). Impact of covid-19 pandemic on micro, small, and mediumsized enterprises operating in pakistan. Research in globalization, 2, 100018.

Simiyu, f. M., namusonge, g. S., \& sakwa, m. (2017). Effect of government policy and regulations on the growth of entrepreneurial women micro and small enterprises in trans nzoia county, kenya.

Uu nomor 20 tahun 2008 tentang usaha mikro, kecil, dan menengah

Vixathep, s. (2017). Entrepreneurship, human and social capital, and government policy in small and medium enterprise development in laos. Japan social innovation journal, 7(1), 33-50.

Widjadja, y. R., alamsyah, d. P., rohaeni, h., \& sukanjie, b. (2018). Peranan kompetensi sdm umkm dalam meningkatkan kinerja umkm desa cilayung kecamatan jatinangor, sumedang. Jurnal abdimas bsi: jurnal pengabdian kepada masyarakat, 1(3). 